\section{andinat}

JURNAL PENELITIAN BAHASA, SASTRA, DAN

BUDAYA ARAB

P-ISSN: 2615-7241 | E-ISSN: 2721-480X // Vol. 2 No. 2 | 137-148

(1) https://ejournal.upi.edu/index.php/alsuniyat/index

\title{
ANALISIS IQTIBĀS DALAM SYAIR IBNU JABIR AL ANDALUSIA
}

\author{
Sarifah \\ SMP Bina Sarana Cendikia Al Kenzie Bandung, Indonesia \\ E-mail: syarifah.ar@yahoo.com
}

\begin{abstract}
:
Al-Qur'an has the beautiful meaning and language style that can reach the soul of the listene From there Balägah science appear that the suitability of fluent and proper sentence could be applied to the meaning of appropriate lafaz. In Balāgah science there are three own discussion namely: ilmu ma'āni, ilmu bayān, and ilmu badī'. Iqtibās is one of part ilmu badi', which make many Arabic poets that cite Al-Qur'an, because of the sentences and the selection of lafaz which make the poets fascinated by the beauty of its language style. This research used a descriptive analsis of qualitative research on the poem of Ibnu Jabir Al Andalusia.
\end{abstract}

\section{Keywords:}

Iqtibās; Poem; Al-Qur'an

\begin{abstract}
Abstrak
Al-Qur'an memiliki keindahan makna dan gaya bahasa yang dapat menyentuh jiwa pendengarnya. Dari situlah ilmu Balāgah muncul agar kesesuaian kalimat yang fasih dan tepat dapat dirapkan terhadap makna dalam lafazlafaz yang sesuai. Dalam ilmu Balāgah terdapat tiga pembahasannya sendiri yaitu; ilmu ma'āni, ilmu bayān, dan ilmu badī'. Iqtibās merupakan salah satu bagian dari ilmu badī', Hal tersebut yang membuat banyak penyair penyair arab yang mengutip Al-Qur'an, karena kalimat- kalimat dan pemilihan lafaz-lafaz nya yang membuat para penyair terpesona dengan keindahan gaya bahasanya. Penelitian ini menggunakan penelitian kualitatif analisis deskriptif pada syair Ibnu Jabir Al Andalusia.
\end{abstract}

Kata Kunci:

Iqtibās; Syair; Al-Qur'an

\section{PENDAHULUAN}

Al-Qur'an adalah kitab suci umat Islam. Mukjizat ini diturunkan oleh Allah melalui malaikat Jibril As kepada Nabi Muhammad Saw. Sebagai panduan untuk manusia (Abdullah dkk., 2016). Sejak zaman dahulu Al-Qur'an kitab suci umat islam diturunkan, banyak orang yang terkagum-kagum dengan susunan bahasa Al-Qur'an dan keindahan uslubnya, Dari segi bahasa Al-Qur'an memiliki tingkat faṣahah dan balāgah yang tinggi, mulai dari aspek makna hingga lafaz, sehingga muncullah ilmu yang khusus mempelajari tentang keindahan makna dan lafaz dalam Al-Qur'an yaitu ilmu balāgah (Uyubah dkk., 2019).

Oleh karena itu, banyak di antara mereka mencoba untuk menandingi ketinggian bahasa Al-Qur'an, namun semua yang mereka lakukan menemui kegagalan dan tidak mungkin dapat menandingi keindahan susunan bahasa Al-Qur'an. Dalam Al-Qur'an terdapat banyak lafal yang mempunyai tingkat fașahah dan balāgah yang tinggi yang mengandung nilai-nilai keindahan 
dan kedalaman makna tertentu, sehingga lafal-lafal tersebut menarik untuk dipelajari. (Multazim \& Busri, 2018:28).

Qistifani (2019:41) menandaskan bahwa setiap bahasa mempunyai struktur kalimat berbeda-beda dan mempunyai ciri khasnya masing-masing. Bahasa yang baik dan komunikatif tersusun dari kalimat yang baik pula. Kalimat yang tersusun sesuai dengan struktur bahasa yang baik akan memudahkan mitra tutur dalam memahami apa yang dibicarakan oleh penutur. Ilmu balāgah adalah salah satu ilmu kesusastraan Arab yang memiliki peran penting dalam salah satu upaya kemahiran berbahasa Arab. Oleh karena itu, Ardiansyah (2016:452) bahasa Arab hadir dengan keagungan dan kesempurnaanya yang mengungguli bahasa-bahasa lain di dunia, baik dilihat dari sudut pandang banyaknya pembendaharaan mufradātnya (kosakata) maupun dari sistem kebahasaannya (gramatikanya). Balāgah memiliki fungsi mempercantik suatu frasa atau kalimat sehingga dapat terdengar indah saat di ucapkan. Ilmu balāgah yang khusus membahas ihwal keindahan makna dan lafaz adalah ilmu badī (Al Jarim \& Amin, 1994).

Ada dua aspek bidang kajian ilmu badī', yaitu muhassināt lafziyah (keindahan lafaznya) dan muhasanāt ma'nawiyah (keindahan maknanya). Di dalam muhasināt lafẓiyah terdapat satu kajian yang membahas tentang gaya bahasa sastra yang mengutip ayat atau hadis kedalam rangkayan kalimat sastra tersebut, tanpa menjelaskan bahwa petikan itu berasal dari Al-Qur'an atau hadis. Disisi lain, Al-Hasyimi (1960:99) menegaskan bahwa badī’ suatu ilmu yang dengannya dapat diketahui bentuk dan keutamaan yang dapat menambah keindahan serta dapat menambah nilai estetika ungkapan.

Banyak kita temukan di beberapa tulisan sastra, baik itu berupa sajak ataupun prosa yang mengutip atau menggunakan rangkaian kata yang berasal dari ayat-ayat Al-Qur'an maupun hadis Nabi Saw., namun sangat disayangkan ada di antaranya yang tidak pada tempat yang layak, dan ada beberapa ulama yang tidak membolehkan.

Selain itu, ada juga yang tidak memerhatikan bagaimana mengutip atau mengambil beberapa ayat maupun hadis yang kemudian dimasukan dalam rangkaian sajak, syair ataupun prosa tersebut, sehingga tidak memperdulikan mana yang boleh dan mana yang tidak boleh. Susunan huruf dan kata-kata yang terdapat di dalam Al-Qur'an tersusun secara teratur dan menjadikan indah dalam pengucapan setiap ayat-ayatnya. Keistimewaan bahasa di dalam AlQur'an terletak di dalam gaya pengungkapannya, antara lain kelembutan dalam jalinan antara huruf dan kata dengan lainnya. 
Kelembutan dan keindahan Al-Qur'an serta keterjagaannya dalam menyimpan makna membuat para penyair tak pernah ragu untuk sekedar mengutip setiap kalimat dalam AlQur'an, hal ini di karenakan Al-Qur'an memiliki keistimewaan dan kelembutan kata, serta keindahannya dan memiliki makna yang mendalam, serta keterjagaanya yang membuat para penyair merasa tak perlu mencantumkan sumber kutipan yang ditulis dalam syairnya, karena kalimat tersebut pasti takkan dirasa asing untuk diperdengarkan. Dalam ilmu balāgah terdapat pembahasan yang menjelaskan bahwa mengutip prosa atau puisi dari ayat yang ada dalam AlQur'an, boleh untuk tidak mencantumkan atau menjelaskan bahwa kutipan tersebut berasal dari Al-Qur'an atau hadis.

Iqtibās dapat menyalin atau mengutip Al-Qur'an dan hadis dan dapat di jadikan syair atau prosa tanpa menjelaskan kutipan tersebut dari Al-Qur'an. Berbeda halnya dengan bahasa Indonesia, yang di setiap kegiatan pengutipannya harus mencantumkan nama atau judul buku sebagai rujukan untuk karya ilmiahnya, hal ini di maksudkan untuk menghindari plagiarisme sehingga hasil karya ilmiahnya yang dapat di pertanggungjawabkan.

Secara leksikal, iqtibās bermakna menyalin dan mengutip. Sedangkan secara terminologis, iqtibās adalah kalimat yang disusun oleh penulis atau penyair dengan menyertakan petikan ayat atau hadis ke dalam rangkaian kalimatnya tanpa menjelaskan bahwa petikan itu berasal dari Al-Qur'an atau hadis. Selain itu iqtibās juga menyisipkan lafaz Allah dan ditulis ulang melalui prosa ataupun sajak kedalam bentuk puisi.

Iqtibās merupakan bagian dari ilmu badī’ yang merupakan salah satu bagian dari ilmu balāgah, fokus penelitian ini menganalisis tentang syair Ibnu Jabir Al Andalusia, yang iqtibāsnya berasal dari Al-Qur'an maupun dari hadis. Ibnu Jabir Al Andalusia ini merupakan salah satu penyair yang bentuk syair atau prosanya sering mengutip ayat-ayat Al-Qur'an atau hadis. Tidak mengherankan bahwa Ibnu jabir Al Andalusia mengutip hadis dan Al-Qur'an dalam menciptakan dasar yang kuat terhadap nilai-nilai budaya, sehingga dapat kita temukan ayatayat Al-Qur'an atau hadis yang banyak dikutip oleh Ibnu Jabir Al Andalusia, bahkan pada beberapa kesempatan dia mengutip Al-Qur'an dalam ucapannya.

Salah satu contoh syair Ibnu Jabir Al Andalusia adalah

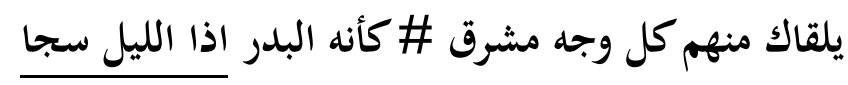

Dari bait di atas, iqtibāsnya berada pada bait syair yang bergaris bawah, tepatnya pada kata اذا الليل سجا itu merupakan iqtibās dari Al-Qur'an yaitu kutipan dari surah Adh-dhuha ayat 2. 
Menurut Ibnu Jabir Al Andalusia yang dinukil oleh Ar-Rukābiy (2012) bahwa kutipan terbagi menjadi empat jenis, yaitu: pertama, kutipan prosa dari Al-Qur'an. Kedua, kutipan puisi dari Al-Qur'an. Ketiga, kutipan dari hadis, dan keempat, kutipan puisi dari hadis Nabi. Jenis kutipan teks oleh Ibnu Jabir Al Andalusia banyak mengungkap kedalaman budaya, religiusnya serta status keilmuannya, dan lebih bersifat indikatif dan bukan tekstual yang mana syair tersebut mencerminkan sejauh mana pengaruhnya. Salah satu contoh syair Ibnu Jabir dalam penggunaan hadis Nabi sebagai berikut.

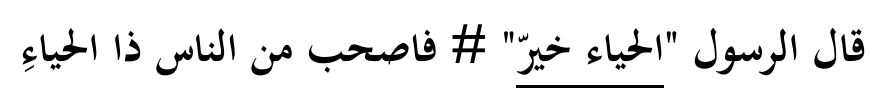

Dari bait di atas, iqtibāsnya berada pada bait syair yang bergaris bawah, tepatnya pada kata الحياء خير, itu merupakan iqtibās dari hadis.

Namun ada beberapa para ulama yang melarang pengutipan Al-Qur'an. Hal ini disebabkan karena kekhawatiran sebagian para ulama yang takut akan pemuliaan Al-Qur'an dapat merubah isi atau bentuk Al-Qur'an itu sendiri, selain itu Al-Qur'an merupakan pedoman atau petunjuk bagi umat islam sehingga Al-Qur'an sangat di muliakan kedudukanya bagi umat islam.

Para ulama klasik dan modern bersepakat iqtibās dalam sajak diharamkan atau minimal makruh (Suryaningrat, 2007), dengan tujuan untuk menjaga kemurnian Al-Qur'an dari penisbahan dengan Al-Qur'an, hal tersebut berdasarkan firman Allah:

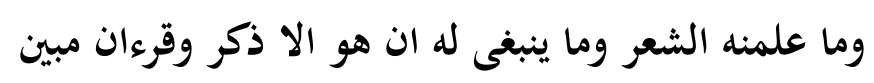

Dan Kami tidak mengajarkan syair kepadanya (Muhammad) dan bersyair itu tidaklah layak baginya. Al-Qur'an itu tidak lain hanyalah pelajaran dan kitab yang memberi penerangan. (Q.S. Yassin: 69).

Ayat di atas menandakan bahwa nabi Muhammad Saw. tidak pernah belajar tentang syair. Adapun ulama kontemporer yang mengharamkan di antaranya Syekh Ibnu Al Utsaimin, beliau berpendapat makruh di dalam sajak dan boleh di dalam prosa. Beliau menjelaskan dalam kitab Syahrul balāgah, bahwa apabila iqtibās di dalam sajak, apabila ia sama dengan makna yang dimaksud maka itu jelas bagiku, hal tersebut tidak boleh dan terlarang, Karena hal tersebut membuat rancu Al-Qur'an dengan sajak.

Suryaningrat (2007) juga menambahkan bahwa sebagian ulama yang lain membolehkan iqtibās dengan Al-Qur'an di dalam sajak apabila tidak mengandung makna yang terlarang seperti, bentuk- bentuk nasihat, tażkirah, atau pemujian terhadap Rasullullah Saw.. Namun ada sebagian yang membolehkan hal tersebut, mereka beralasan dengan beberapa bait sajak beliau 
mengambil ayat-ayat Al-Qur'an, maka berkatalah Imam Suyuti di dalam kitab Al Itqān:"Syekh Tajuddin Bin Subki di dalam tulisannya tentang Imam Abu Mansur Abdul Qohar bin Thohir At Tamimi al Baghdadi salah seorang pembesar ulama bermazhab Syafi'i, berbunyi :

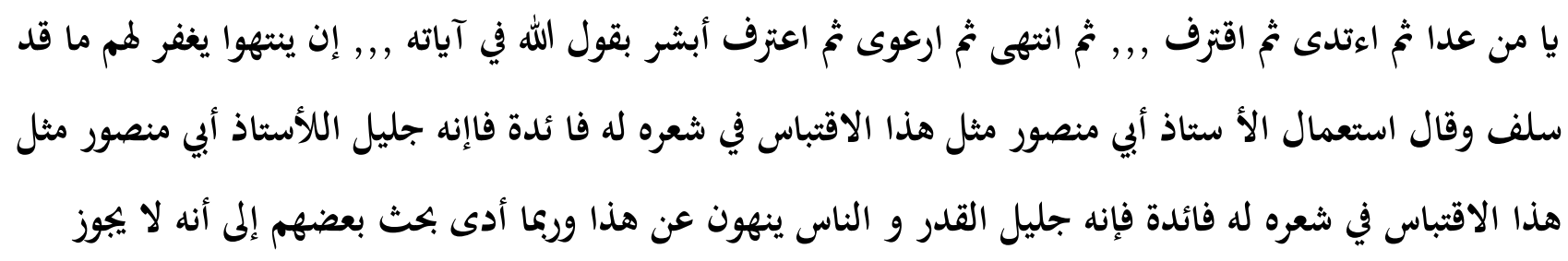

Abu Mansur di dalam sajaknya ini menggunakan iqtibās hal tersebut memiliki faedah, bahwasannya ia jelas dalam meletakan batasan dan orang lain di larang dalam hal ini. Para ulama bersepakat, apabila pengutipan itu dengan tujuan untuk olok- olokan, penghinaan dan canda gurau, hal tersebut dilarang sebagai bentuk pemuliaan terhadap Al-Qur'an atau Kitab Allah.

Lain halnya sebagaimana ketika Rasullullah menaklukan kota Makkah, beliau mengucapkan kata-kata yang bertujuan untuk menusuk berhala-berhala yang ada, dengan ucapannya:

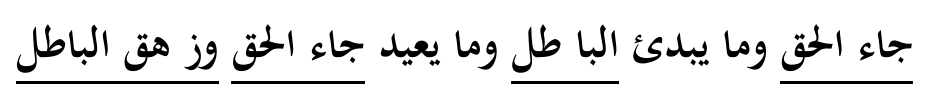

"telah datang kebenaran maka tenggelamlah kebatilan, apabila kebenaran itu sudah kembali akan musnahlah kebatilan".

Dari bait di atas, iqtibāsnya berada pada bait syair yang bergaris bawah, tepatnya pada kalimat جاء الحق وز هق الباطل, itu merupakan iqtibās dari Al-Qur'an yaitu kutipan dari surah Al Isra ayat 111 .

Hal seperti ini diperbolehkan, karena sudah terjamin kejelasannya dan tidak diragukan lagi, maka ulama pun membolehkan iqtibās dalam sajak jika memang tujuan iqtibāsnya jelas dan tidak ada maksud untuk mengolok-olok.

\section{METODE}

Jenis penelitian ini merupakan penelitian kualitatif analisis deskriptif. Jenis penelitian ini menghasilkan data deskriptif berupa kata-kata tertulis atau lisan dari orang-orang dan perilaku yang diamati (Moleong, 2000:3). Objek kajian penelitian ini yaitu menganalisis iqtibās yang ada pada syair Ibnu Jabir Al Andalusia, iqtibās dari Al-Qur'an maupun hadis, yang menitikberatkan pada analisis kajian ilmu badī' yaitu iqtibās serta Al-Qur'an dan jurnal-jurnal yang relevan dengan penelitian. 
Adapun teknik pengumpulan data berupa observasi tidak langsung. Menurut Ainin (2016:126) bahwa observasi tidak langsung dilakukan dengan cara mengkaji dokumen maupun laporan yang dipersiapkan oleh orang lain atau sudah ada, dalam analisis penelitian ini adalah syair dari Ibnu jabir Al Andalusia, iqtibās dari Al-Qur'an maupun hadis.

\section{HASIL DAN PEMBAHASAN}

Banyaknya syair maupun prosa yang terdapat pada kutipan Al-Qur'an atau hadis telah menjelaskan bahwa keunikan bahasa arab dan keindahan Al-Qur'an ataupun hadis, baik secara lafaz maupun makna telah kita sadari. Kita juga dapat menggunakan iqtibās sebagai media dakwah, memberi nasihat, memotivasi, juga dapat menjadi alat untuk mendapatkan hidayah dan pengajaran serta pembelajaran yang berkualitas dalam kehidupan sehari-hari. Adapun macam-macam iqtibās dalam ilmu badī' ada tiga:

\section{Tsabitul ma'āni}

Tsabitul ma'āni yaitu tidak ada perubahan dari sisi makna asalnya. Dengan kalimat lain, mengutip dari Al-Qur'an maupun hadis dengan menggunakan redaksi serta makna yang sama dengan yang ada dalam Al-Qur'an maupun hadis tersebut. Seperti kata syair:

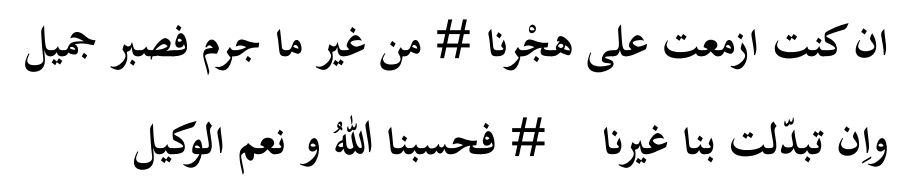

Artinya : "Kalau kau bermaksud meninggalkan kami tanpa dosa, maka kesabaran baik sekali bagi kami. Dan kalau kau bermaksud mencari pengganti selain kami, maka Allah jualah yang mencukupi kami dan sebaik-baik wakil." Iqtibās disini terletak pada lafaz فصبر جميل dua redaksi tersebut dengan redaksi yang terdapat dalam redaksi aslinya.

Contoh lain dari iqtibās jenis ini adalah:

$$
\text { ستبقي لها فى مضمر والحشا \# سريرة ود يوم تبلى السرائر }
$$

Dari bait di atas, iqtibāsnya berada pada bait syair yang bergaris bawah, tepatnya pada kata يوم تبلى السرائر itu merupakan iqtibās dari Al-Qur'an yaitu kutipan dari surah At-thariq ayat 9 .

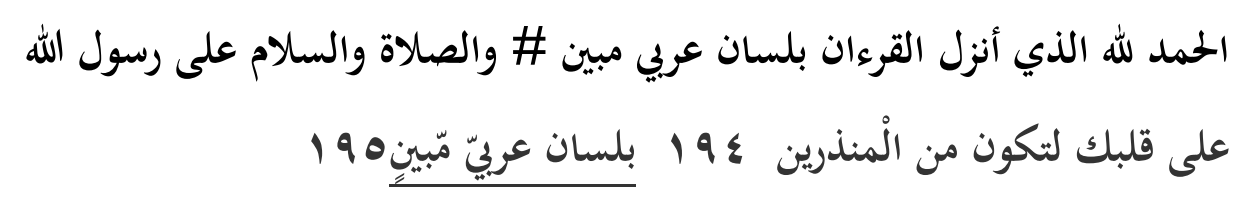


Dari bait di atas, iqtibāsnya berada pada bait syair yang bergaris bawah, tepatnya pada

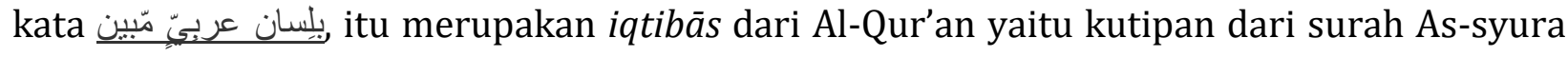
ayat 195 .

\section{Muhawwal}

Muhawwal yaitu yang diubah dari makna aslinya. Yaitu membuat iqtibās dengan mengubah arti dari arti aslinya, dari segi lafaz tidak berubah. Seperti kata ibnu rumi:

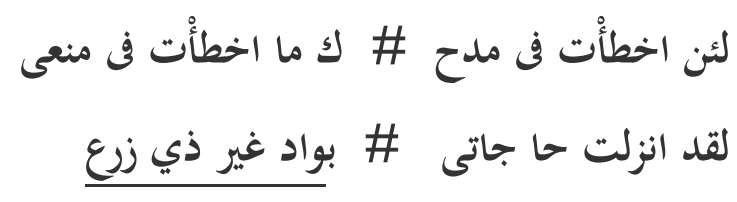

"Kalau aku salah dalam memujimu, maka aku tidak salah dalam menahan nafsuku. Sungguh engkau telah menempatkan kebutuhanku pada lembah yang tidak ada tumbuhtumbuhannya."

Syair tersebut merupakan pindahan dari ayat:

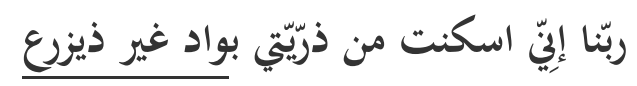

Maksud ma'na yang terkandung dalam Al-Qur'an ialah: “lembah yang tidak bermata air dan gersang tidak ada tumbuh-tumbuhan. yaitu: kota Makkah. Adapun maksud syair tersebut adalah: laki-laki yang sunyi dari kebaikan dan tidak ada gunanya."

3. Berubah sedikit wazannya. Seperti kata syair:

$$
\text { قد كان ماخفت ان يكونا \#\# إِنّا إلى الله راجعوْن }
$$

Artinya: Sungguh telah terbukti apa yang kau takuti. Sesungguhnya kami semua kembali kepada Allah.

Syair di atas berasal dari ayat:

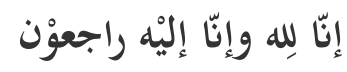

Artinya: "Sesungguhnya kami milik Allah dan hanya kepadaNya kami kembali."

Pada syair di atas maknanya tidak berbeda namun teks diubah sedikit.

Contoh iqtibās di atas menunjukkan perubahan dari aslinya, yaitu dari ayat di atas tersebut, kemudian dimodifikasi sedemikian rupa sehingga berubah dari bentuk aslinya.

Contoh yang lain seperti:

$$
\text { قد تقطع الرحم القريب و تكفر النع \# مى ولا كتقارب القلبين }
$$




$$
\text { إن الرحم تقطع وإن النعم تكفر و لن ترى مثل تقارب القلوب }
$$

Dari bait di atas ini iqtibāsnya berada pada bait syair yang bergaris bawah, tepatnya pada kata تقارب القلوب, تكفر, الرحم تقطع itu merupakan iqtibās dari pada hadis Nabi.

Contoh yang lain lagi seperti:

$$
\begin{aligned}
& \text { أحييكم جميعا بتحية الإسلام تحية طيبة مباركة من عند الله فسلام الله عليكم ورمثته وبركاته } \\
& \text { فستِّمواعلى أنفسكم تحَيَّة مَّْ عند اللهِهِ مبركة طيّبة }
\end{aligned}
$$

Dari bait di atas, iqtibāsnya berada pada bait syair yang bergaris bawah, tepatnya pada kata_تحية طيبة مباركة من عند اله An-nur ayat 61.

Salah satu contoh penggunaan pada hadis nabi yaitu sebagai berikut:

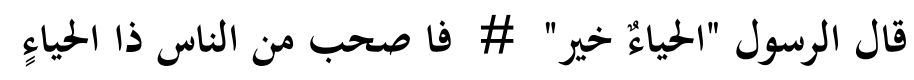

Dalam bait sebelumnya, iqtibās dari hadisnya, mengatakan: "kesederhanaan itu baik" atau "kesederhanaan adalah segalanya". Ucapan lainnya yaitu:

$$
\text { اذا ما أنت لم تستح فاصنع \# كما تختار وافعل ما تشاء }
$$

Dari bait di atas ini iqtibāsnya berada pada bait syair yang bergaris bawah. Syair tersebut merupakan iqtibās dari Hadis. Sanad hadisnya yaitu: عن أبي مسعود عقبة بن عمرو الأنَصاريّ البدريّ رضي اللهُ عنه قال: قال رسول اللَّه صلى الله عليه و سلم "إنّ

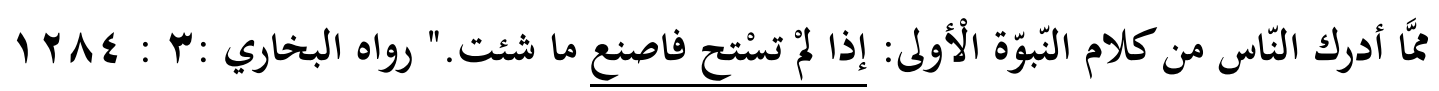

Isyarat tersebut mengacu pada kata-kata Nabi Muhammad Saw.: Dari Abu Mas'ud Uqbah bin Amr Al Anshary Al Badry radhiallahuanhu dia berkata, Rasullullah Saw. Bersabda "sesungguhnya ungkapan yang telah dikenal orang-orang dari ucapan nabi-nabi terdahulu adalah": Jika engkau tidak malu perbuatlah apa yang engkau suka. Ibnu Jabi Al Andalusia mengiqtibāskan teks dari hadis Nabi yang menyebutkan sepuluh kebajikan para sahabat dan penghuni surga, dan ahlul bait di dalam ucapannya:

$$
\text { الا أن أصحابي نجوم من اقتدى \# بم في سبيل العلم والحلم يهتدي }
$$

Dari bait di atas diadaptasi dari hadis 


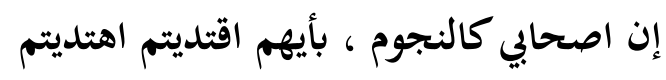

Iqtibās teks dari Ibnu Jabir Al Andalusia, yaitu:

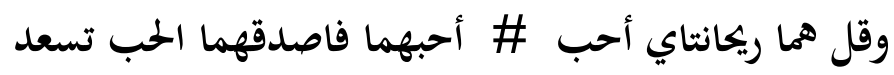

Referensi atau rujukan terhadap perkataan atau bait Ibnu Jabir Al Andalusia, Dari Abu Hurairah RA berkata: Rasulullah Saw mencium Al Hasan bin Ali, di hadapan Al Aqra' bin Habis At Tamimiy yang sedang duduk. Lalu Al Aqra' berkata: 'sesungguhnya aku memiliki sepuluh anak dan aku belum pernah menciumi seorang pun. Lalu Rasulullah Saw mendatanginya dan bersabda: "Barang siapa yang tidak menyayangi maka tidak akan disayangi" (HR. Al Bukhari).

Dan iqtibās Ibnu Jabir Al Andalusia muncul seperti berikut ini:

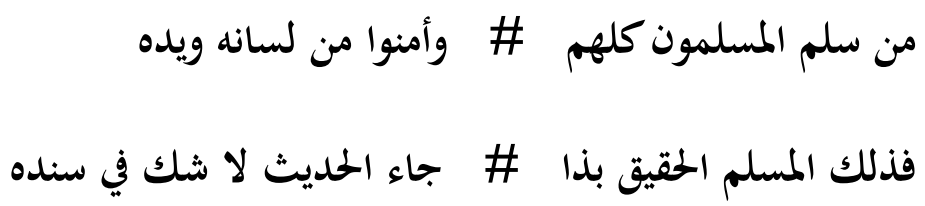

Bait di atas jelas dari hadis mulia "seorang muslim adalah orang yang telah membebaskan muslim dari lidah dan tangannya" dan terlihat juga dalam ucapannya:

$$
\text { إنما الاعمال بالنيات قد \# نصه عن سيد الخلق عمر }
$$

Pada bait diatas menjelaskan tentang hadis Nabi dari Amirul Mu'minin, (Abu Hafsh atau Umar bin Khottob ra) dia berkata: "Aku pernah mendengar Rasulullah Saw bersabda: 'sesungguhnya seluruh amal itu tergantung kepada niatnya, dan setiap orang akan mendapatkan sesuai niatnya. Oleh karena itu barang siapa yang berhijrah karena Allah dan Rosul-Nya, maka hijrahnya kepada Allah dan Rosul-Nya. Dan barang siapa yang berhijrah karena (untuk mendapatkan) dunia atau karena wanita yang ingin dinikahinya maka hijrahnya itu kepada apa yang menjadi tujuannya (niatnya)".

Adapun jenis iqtibās syari' yaitu semua yang dimaksud oleh penyair itu merujuk pada hadis tanpa mematuhi kata dan komposisinya. Di antara kutipan indikatif adalah perkataan Ibnu Jabir Al Andalusia dalam Imam Ali bin Abi Thalib dalam perkatannya:

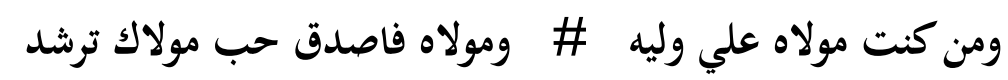


Bait di atas mengacu pada hadis Rasullullah Saw.: "siapapun anda tuannya, ini adalah tuannya, ya Allah, dari orang tuanya dan kembali dari penghuninya". Kita mungkin menemukan bahwa Ibnu Jabir Al Andalusia mengiqtibāskan lebih dari satu hadis Nabi Saw. di satu bait, seperti dalam ucapannya :

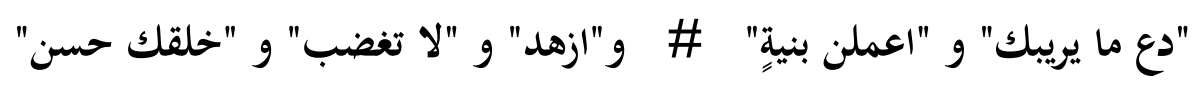

Perkataannya, "tinggalkanlah apa yang meragukanmu," merujuk pada hadis nabi Saw. : "د "دع ما يريبك الى مـا لا يريبك " mengatakan 'dan setiap perbuatan dengan niat' referensi ini merujuk

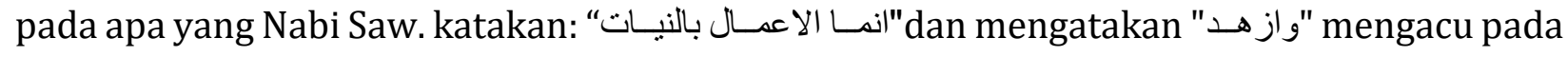

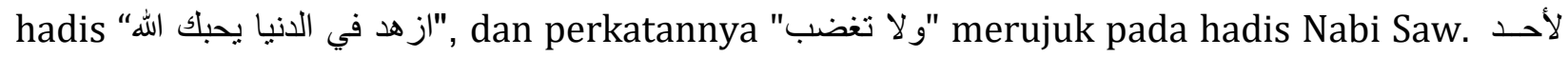
وخالق الناس بخلق " merujuk pada hadis "وخلق لـ حسـن adapun katakannya , "الصــحابة "لا تغضــب"

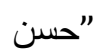

Dan Ibnu Jabir Al Andalusia mengatakan:

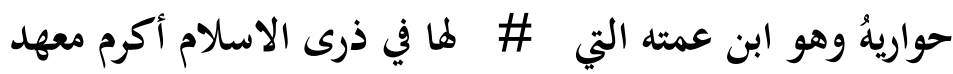

Sejatinya, bait ini merujuk pada: “ ان لكل نبي حواريأوحواري الزبير "ditemukan juga bahwa Ibnu Jabir Al Andalusia Merujuk pada kata- kata Nabi Muhammad SAW., Saad Ibnu Abi Waqosh dan dia menyebutnya : " اللهم استجب لسعدٍ اذا دعالك dalam perkataanya :

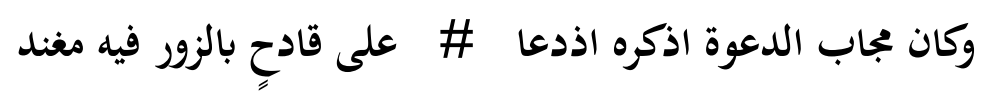

dia juga mengatakan:

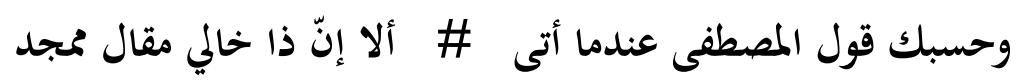

"Bذا خحالي فليربي امرؤ خاله " :

Dan perkataan Hamzah Ibnu Muthalib As juga :

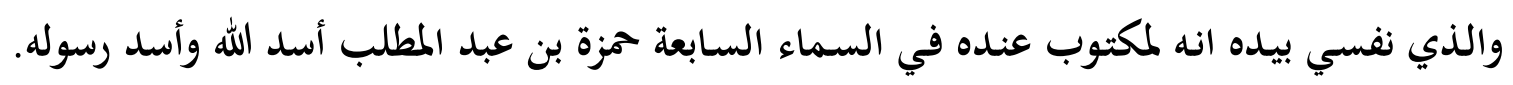

Dan dia juga menyebutkan Al Abbas as Ibnu Abdul Muthalib paman Rasullullah Saw. :

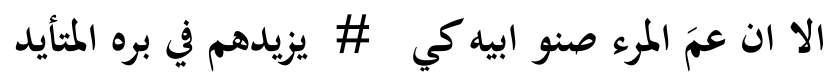


di dalam bait di atas Iqtibās syair tersebut berasal dari hadis Nabi Saw. berkata :

$$
\text { فانه بقية آبائي وان العم صنو الأب" ، }
$$

Adapun seperti yang di sebutkan oleh Abdullah Ibnu Abbas sepupu Nabi Saw. mengatakan:

$$
\text { فأصبح حبر الامة العالم الذي \# به يقتدي في علمه كل مقتدي }
$$

Saat beliau mengutip syair ini dari perkataan Nabi Muhammad Saw.

$$
\text { "حبر الامة وعالمها وترجمان القرآن" }
$$

Jafar bin Abi Thalib As juga menyebutkan dalam perkataanya :

$$
\text { وقال له المختار انك مشبة لخلقي و خلقي فهو أكرم مهتدي }
$$

Iqtibās ini berasal dari Nabi Muhammad Saw., kepada Jafar As :

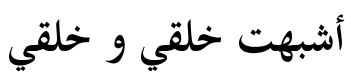

Seperti yang di sebutkan oleh Hasan dan Husein As pada syair Ibnu Jabir Al Andalusia dalam ucapannya :

$$
\text { هما قر تا عين الرسول وسيدا \# شباب الورى في جنة الحلد في غدِ }
$$

Dan dalam bait tersebut berujuk pada : " الحسن و الحسين سيدا شباب أهل الجنة " Ibnu Jabir Al Andalusia juga menyebutkan pada Hasan As :

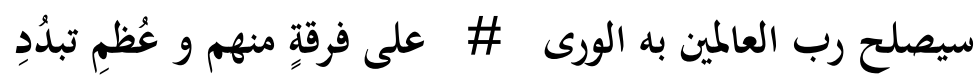

Bait di atas merupakan Iqtibās dari Rasullullah Saw., di dalam hadis untuk Hasan As:

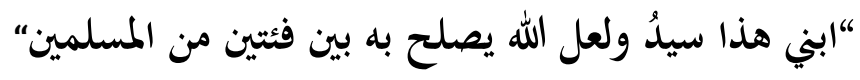

\section{SIMPULAN}

Berdasarkan analisis yang telah dilakukan oleh peneliti terhadap Syair Ibnu Jabir Al Andalusia, iqtibās dari Al-Qur'an maupun Hadis dapat disimpulkan bahwa penjelasan syair Ibnu Jabir Al Andalusia di atas, dapat diketahui bahwa Ibnu Jabir Al Andalusia mengutip dari 
hadis kenabian dengan baik secara tekstual maupun teologis, jenis- jenis iqtibās berupa syair Ibnu Jabir juga bersifat tekstual dan indikatif. Disetiap bait syair Ibnu Jabir Al Andalusia cenderung menitikberatkan kepada kepribadian dan agama Islam.

Karena syair Ibnu Jabir Al Andalusia ini baik secara tekstual tidak sedikit para penyair yang terisnpirasi dari bait bait puisi nya, hal ini dikarenakan Ibnu Jabir Al Andalusia mengutip bait syair dari Al-Qur'an dan hadis sehingga keindahan dan makna yang tersimpan menjadi sangat indah di dengarkan.

\section{DAFTAR PUSTAKA}

Abdullah, M, dkk. (2016). Tanggung Jawab Hufaz Menurut Al-Nawawi Dalam Al-Tibyan Fi Adabil Hamalatil Quran. International Journal of Humanities Technology and Civilisation,1(2), 42-49.

Ainin, Moh. (2016). Metode Penelitian Bahasa Arab. Malang: CV. Bintang Sejatera.

Al-Hasyimi, Ahmad. (1960). Jawahir Al-Balaghah Fi Al-Ma'aniy Wa Al-Bayan Wa Al-Badī'. Indonesia: Maktabah Dar Ihya Al-Kutub Al-Arabiyah.

Al-Jarim, Ali \& Amin, Musthafa. (1994). Terjemahan Al-Balaaghatul Waadhihah. Cet. 1. Bandung: Sinar Baru Algensindo.

Ardiansyah. (2016). AL-MUHASSINĀT AL-BADİ'IYYAH PADA AYAT-AYAT HUKUM TENTANG BERJUANG DI JALAN ALLAH. al-Maslahah, 12(2), 447-464.

Ar-Rukābiy, Anāhid 'Abd al-Amīr. (2012). AL IQTIBĀS MIN AL-HADĪTS AN-NABAWIY ASYSYARĪF IBNU JABĪR AL ANDALUSIY. IRAQI Academic Scientific Journals, 18 (73), 207-220. Moleong, L. J. (2000). Metodologi Penelitian Kualitatif. Bandung: Rosda Karya.

Multazim, H. \& Busri, H. (2018). AT-THIBAQ DALAM AL-QURAN SURAH AL-BAQARAH-ATTAUBAH (TINJAUAN BALAGHAH). Journal of Arabic Learning and Teaching, 7(1), 27-36. Qonita, V. Q. (2019). ANALISIS KONSTRASTIF KALIMAT SYARAT BAHASA ARAB DAN BAHASA INDONESIA. ALSUNIYAT: Jurnal Penelitian Bahasa, Sastra, dan Budaya Arab, 2(1), 40-57.

Suryaningrat, Erwin. (2007). Pandangan Ulama tentang Iqtibās dengan ayat Alquran dan Hadis Nabi Saw. Jurnal At-Ta'lim,16(2), 396-408.

Uyubah, R. M., Mahliatussikah,H., \& Alfan, M..(2019). Uslub Jinas dalam Al-Quran Juz 29 (Studi Analisis Balaghah). Prosiding Seminar Nasional Bahasa Arab Mahasiswa III Kajian tentang Bahasa, Sastra dan Budaya Arab di Indonesia. Malang: Universitas Negeri Malang. 